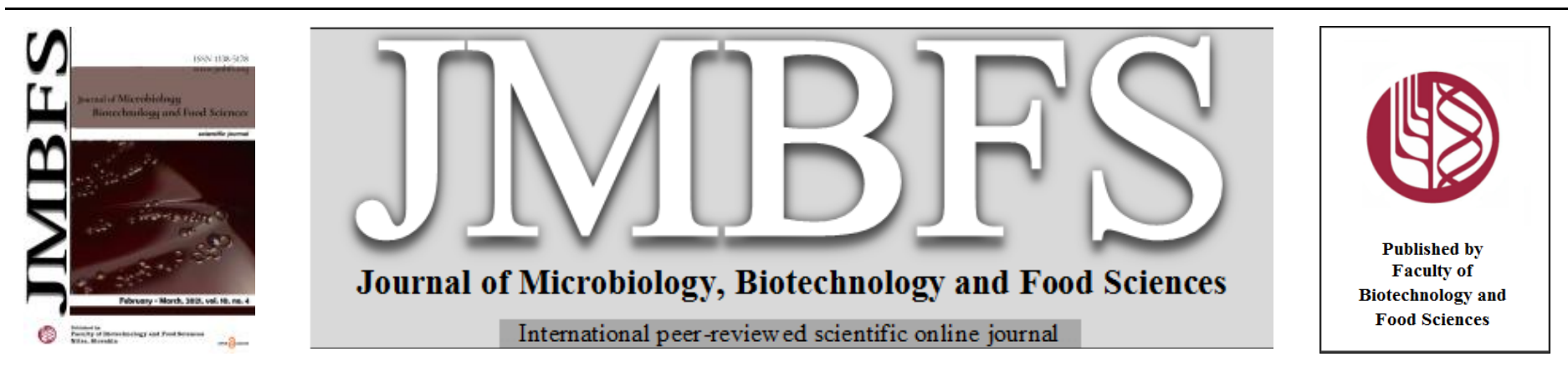

\title{
DEVELOPMENT OF DIRECT EXPANDED HIGH PROTEIN SNACK PRODUCTS FORTIFIED WITH SACHA INCHI SEED MEAL
}

\section{Sutharut Jiapong ${ }^{1}$ and Khanitta Ruttarattanamongkol ${ }^{2 *}$}

\author{
$\operatorname{Address}(e s):$ \\ ${ }^{1}$ Naresuan University, Faculty of Agriculture Natural Resources and Environment, Department of Agro-Industry, 65000, Phitsanulok, Thailand, Phone \\ number:+66989642397. \\ ${ }^{2}$ Naresuan University, Faculty of Agriculture Natural Resources and Environment, Department of Agro-Industry, 65000 , Phitsanulok, Thailand, Phone number: +66 55 \\ 962735 .
}

*Corresponding author: khanittar@nu.ac.th

doi: 10.15414/jmbfs.2021.10.4.680-684

\section{ARTICLE INFO}

Received 23. 4. 2020

Revised 31. 10. 2020

Accepted 9. 11.2020

Published 1.2. 2021

Regular article

open $\odot$ access

\begin{abstract}
Direct expanded or ready-to-eat (RTE) snacks fortified with Sacha inchi (Plukenetia volubilis L.) seed meal, a by-product of oil extraction process, were developed using a co-rotating twin-screw extruder. The composite blends of various amounts of Sacha inchi seed meal (20-60\%), rice flour (40-80\%) were prepared for extrusion cooking at 10-15\% in-barrel moisture, $10.88-15.14 \mathrm{~kg} / \mathrm{h}$ of feeder speed and $400 \mathrm{rpm}$ of screw speed. The final products were characterized in terms of physical properties (color, texture, density, expansion ratio, water absorption index (WAI), water soluble index (WSI), proximate compositions, sensory, in-vitro digestibility and antioxidant activities, respectively. The results indicate that level of Sacha inchi seed meal significantly affected the physical characteristics by increasing hardness and density of the snack products. Expansion ratio and WAI of the snack products were decreased by increasing the level of Sacha inchi seed meal. The sensory evaluation result shows that all snack formulations were generally accepted by consumers. The snack fortified with $40 \%$ Sacha inchi seed meal was the most acceptable product based on the overall characteristics. It contained highest protein content $(24.94 \pm 0.07 \%)$ with approximately $1.79 \pm 0.16 \%$ fiber, $2.09 \pm 0.00 \%$ fat, $3.42 \pm 0.02 \%$ ash, $5.61 \pm 0.14 \%$ moisture, and $62.27 \pm 0.11 \%$ carbohydrate, respectively. Total digestibility of the snack was $41.11 \%$ in which $12.36 \%$ and $28.75 \%$ were digested in stomach and small intestine, respectively. The total phenolic content (TPC) was $205.46 \pm 11.66 \mu \mathrm{g}$ GAE/g dry weight snack and the Trolox equivalent antioxidant capacity (TEAC) was $135.40 \pm 1.10 \mu \mathrm{mol} \mathrm{TE} / \mathrm{g}$ dry weight snack. The extruded product developed from Sacha inchi seed meal is protein-rich and suitable for health-conscious consumers.
\end{abstract}

Keywords: Sacha inchi seed meal, Extrusion, Direct expanded product, Ready-to-eat Snack, High protein

\section{INTRODUCTION}

Consumer demand increases for ready-to-eat (RTE) and convenient snack products with high protein and low-calorie. Extrusion technology is widely used in the production of direct expanded or RTE snack products due to its ability to produce a variety of textures and shapes which appeal to consumers. In the extruder, food ingredients are plasticized and cooked by a combination of heat, moisture, pressure and mechanical shear results in gelatinization of starches, denaturation of proteins, inactivation of enzymes that cause food deterioration during storage, destruction of toxic compounds and decreasing the microbial counts in the final products (Liu et al., 2011). Moreover, the extrusion processing increases the protein digestibility (Patil et al., 2016). In Thailand, a large quantity of by-products from seed oil extraction industry is available and underutilized especially seed meal or defatted residue that can cause a major disposal problem for the manufacturers. However, these meals still contain a significant amount and variety of nutrients mainly protein, fiber, phenolics and antioxidants that can be an excellent source for food product fortification. Sacha inchi (Plukenetia Volubilis L.) also known as Inca peanut, is an oleaginous plant that belongs to the Euphorbiaceae family and widely grown in Thailand especially in the North or high land regions. The seeds are high in oil $(54 \% \mathrm{w} / \mathrm{w})$ that contains the essential fatty acids, linoleic acid, $\omega-6(36.8 \% \mathrm{w} / \mathrm{w})$ and linolenic acid, $\omega-3(45.2 \% \mathrm{w} / \mathrm{w})$ and a significant quantity of protein $(27 \%)$ (Harmarker et al., 1992). After extraction of Sacha inchi seed oil, the seed meal or defatted flour contains approximately $56 \%$ protein, $24.36 \%$ carbohydrate, $5.19 \%$ fiber, $5.55 \%$ fat, $6.06 \%$ ash and $2.84 \%$ moisture. Moreover, the World Health Organization (WHO) and Food and Agriculture Organization of the United Nations (FAO) recommend that Sacha inchi seed protein is a high quality protein and has health benefits for human consumption because it contains high amounts of tryptophan $(44 \mathrm{mg} / \mathrm{g})$ and phenylalanine $(3 \mathrm{mg} / \mathrm{g})($ Hanssen and Schmitz, 2011). Therefore, the Sacha inchi seed meal is a promising protein source for palatable higher-protein snack product development. The aim of this study was to develop direct expanded or RTE snacks fortified with Sacha inchi seed meal using a co-rotating twin-screw extruder. The mixture of Sacha inchi seed meal and rice flour at various ratios were prepared for snack production and the samples were evaluated for their physical properties (color, texture, density, expansion ratio, WAI, WSI), proximate compositions, sensory, in-vitro digestibility and antioxidant activities, respectively.

\section{MATERIAL AND METHODS}

\section{Raw materials}

The ingredients used in the extrusion study were Sacha inchi seed meal, rice flour and Salt and Glycerylmonostearate (GMS). The Sacha inchi seed meal, a byproduct of seed oil production was obtained from Thai C.M.S. Standard Industrial Co. Ltd. (Thailand). The Sacha seed meal was milled and sieved through 30 mesh to make a homogenous powder then immediatly placed in the sealed plastic-aluminium foil bag to avoid from light and stored at $4{ }^{\circ} \mathrm{C}$ until further use. Rice flour, Salt and GMS were purchased locally.

\section{Formulations}

Composite blends of various amounts of Sacha inchi seed meal (20-60\%), rice flour $(40-80 \%)$ with fixed amounts of salt $(1 \%)$ and GMS $(1 \%)$ were prepared as shown in table 1 . The ingredients of each formula were mixed well before feeding to the extruder. 
Table 1 Formulations for direct expanded snack production

\begin{tabular}{lccccc}
\multirow{2}{*}{ Ingredients (\%) } & \multicolumn{5}{c}{ Formula (Sacha inchi seed meal : rice flour) } \\
\cline { 2 - 6 } & $20: 80$ & $30: 70$ & $40: 60$ & $50: 50$ & $60: 40$ \\
\hline Sacha inchi & 20 & 30 & 40 & 50 & 60 \\
residue (\%) & 80 & 70 & 60 & 50 & 40 \\
Rice starch (\%) & 1 & 1 & 1 & 1 & 1 \\
Salt (\%) & 1 & 1 & 1 & 1 & 1 \\
GMS (\%) & & & & &
\end{tabular}

\section{Screw configuration and temperature setting of extruder}

Extrusion was performed in a twin-screw extruder (CTE-D25L32, CHAREON TUT CO., LTD., Samutprakan, Thailand). The screw configuration and barrel temperature setting were demonstrated in Figure 1 using a circular die with an opening diameter of $4 \mathrm{~mm}$. During the extrusion process, the in-barrel moisture level, feeder speed, screw speed and torque were adjusted for maximum expansion of the extrudates and specific mechanical energy (SME) values of each product were calculated by Eq. 1 , when $\mathrm{T}=$ Torque $(\mathrm{Nm}) ; \mathrm{N}=$ Screw speed $(\mathrm{rpm}) ; \mathrm{m}=$ Flow rate $(\mathrm{kg} / \mathrm{h})$. The SME is the amount of mechanical energy delivered to extruded material and plays an important role in the starch conversion and responsible for the fragmentation of starch molecules as a result of the applied shear forces, the amylopectin molecules are broken mainly at the $\alpha-1,6$ glycosidic bonds (Gropper et al., 2002). After the extrusion process, the extrudates were dried in a hot air oven at $60^{\circ} \mathrm{C}$ for $30 \mathrm{~min}$, cooled down at ambient temperature and then placed in the sealed plastic-aluminium foil bag until analysis.

\section{$\operatorname{SME}(\mathrm{kW} \cdot \mathrm{h} / \mathrm{kg})=(\mathrm{T} 2 \pi \mathrm{N}) / \mathrm{m} 60)$}

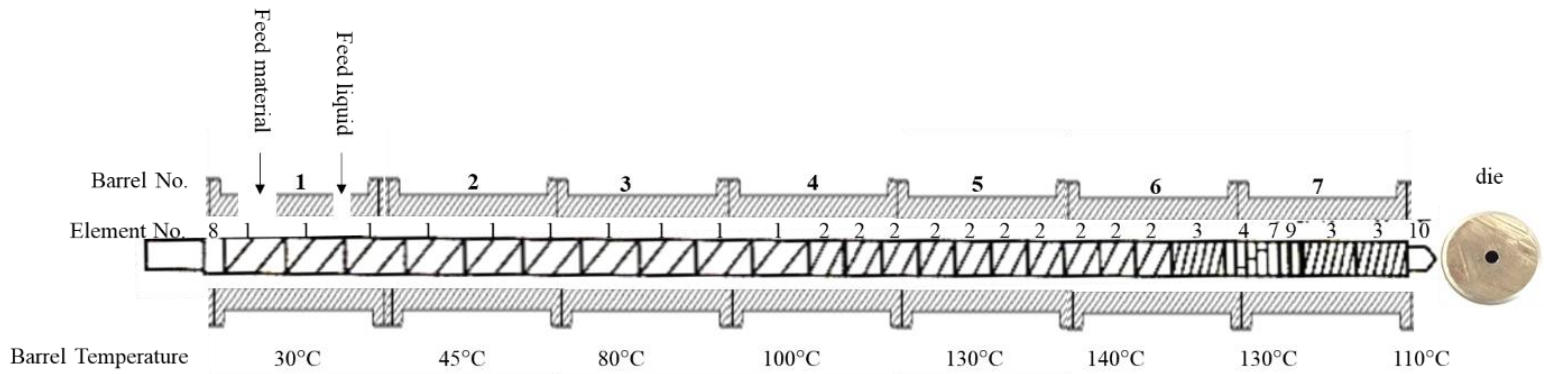

Figure 1 Screw configuration, barrel temperature setting of twin screw extruder for direct expanded Sacha inchi snacks. Element number: $1=\mathrm{CB} 37.5 / 37.5 \mathrm{R}, 2=\mathrm{CB} 25 / 25 \mathrm{R}, 3=\mathrm{CB} 12.5 / 37.5 \mathrm{R}, 4=\mathrm{KB} 37.5 / 5 / 45 \mathrm{deg} \mathrm{R}, 5=\mathrm{KB} 37.5 / 5 / 90 \mathrm{deg} \mathrm{N}, 7=\mathrm{BL} 1.5 / 2,8=$ Spacer Element D17 L9, $9=$ Spacer Element D17 d14.4 L2.5 and 10 = Screw Cap D17 L35.

Table 2 Specific mechanical energy (SME) values and parameters of extrusion process

\begin{tabular}{lccccc}
\hline \multirow{2}{*}{ Extrusion condition } & \multicolumn{5}{c}{ Sacha inchi seed meal : rice flour } \\
\cline { 2 - 6 } & $20: 80$ & $30: 70$ & $40: 60$ & $50: 50$ & $60: 40$ \\
\hline In-barrel-Moisture (\%) & 10 & 10 & 12 & 15 & 15 \\
Feeder speed (kg/h) & 15.14 & 14.49 & 14.16 & 11.93 & 10.88 \\
Screw speed (rpm) & 400 & 400 & 400 & 400 & 400 \\
\%Torque & 60 & 60 & 60 & 60 & 60 \\
SME (kW.h/kg) & $\mathbf{0 . 0 8}$ & $\mathbf{0 . 1 7}$ & $\mathbf{0 . 1 8}$ & $\mathbf{0 . 1 9}$ & $\mathbf{0 . 2 3}$ \\
\hline
\end{tabular}

\section{Physical characteristics}

The color of the direct expanded snack was measured after grinding the snack samples to fine powder and sieving through 60 mesh. The color analysis was performed using a Colorimeter, HUNTER LAB model DP $9000(\mathrm{n}=3)$. The color variables including lightness $\left(\mathrm{L}^{*}\right)$, redness $\left(\mathrm{a}^{*}\right)$ or greenness $\left(-\mathrm{a}^{*}\right)$ and yellowness $\left(b^{*}\right)$ or blueness $\left(-b^{*}\right)$ were measured. Textural quality of the direct expanded snack was determined by means the force needed to break each piece of the snack using an Instron texture analyzer machine (model: 4411). The 500 $\mathrm{kg}$ max load force was applied to measure the energy to break as the unit of kilogram-force milimeter $(\mathrm{kgf} \cdot \mathrm{mm})$ which indicates hardness. Expansion ratio of the extrudates was measured by dividing the diameter of the extrudates with the diameter of the die $(4 \mathrm{~mm})$.

\section{Water absorption index (WAI) and water solubility index (WSI)}

WAI and WSI of the extrudates were determined by the method of NavarroCortez et al. (2016) with some modification. $0.5 \mathrm{~g}$ of grounded snack was weighted into pre-weighted centrifuge tube and dispersed by adding $5 \mathrm{ml}$ of distilled water. The dispersion was shaken in the vortex for $20 \mathrm{sec}$. or until the mixture was thoroughly wetted. The dispersion was left to hydrate for $30 \mathrm{~min}$ before centrifuged at $3000 \mathrm{rpm}$ for $15 \mathrm{~min}$. The supernatant was decanted into a pre-weighted moisture can and dried at $105^{\circ} \mathrm{C}$ for overnight $(12 \mathrm{~h}$.) in a hot air oven. The WAI was calculated as the weight of sediment obtained after removal of the supernatant per weight of initial samples as indicated in Eq. 2. The WSI was the weight of the dry solids in the supernatant expressed as a percentage of the original weight of the dry sample as Eq. 3.

$\mathrm{WAI}=$ weight sediment $/$ weight of sample

WSI $=($ weight of dry solid $/$ weight of sample $) \times 100$

\section{Sensory evaluation}

A hedonic scaling test as described by Lim (2011) was used to determine the liking for the snacks. For this study, 50 consumers received 5 samples and were asked to rate the degree to which they liked the snacks by using a nine-poin hedonic scale $(1=$ dislike extremely, $2=$ dislike very much, $3=$ dislike moderately, $4=$ dislike slightly, $5=$ neither like nor dislike, $6=$ like slightly, $7=$ like moderately, $8=$ like very much, and $9=$ like extremely) to determine the preference in appearance, flavor, texture and overall acceptability. The samples were served in white plastic cups and were identified with random three-digit number. The consumers were instructed to rinse their mouths with water before testing the next samples. Analysis of variance (ANOVA) was used to test of the difference between samples at $95 \%$ level of confidence. Snack gained the highest overall preference scores were subsequently selected for further analysis.

\section{Proximate composition}

The proximate composition of the snacks, including moisture, crude ash, crude fat, crude fiber and crude protein, were determined according to the methods of Association of official analysis chemists (AOAC, 1990). The nitrogen conversion factor used for crude protein calculation was 5.70. The carbohydrate content $(\%)$ was calculated by subtracting the contents of crude ash, fat, fiber and protein from $100 \%$ of dry matter.

\section{In vitro digestibility}

The procedure was done with modified method of Adler-Nissen (1979), Benjakul and Morrissey (1997), and Garret et al. (1999). $1 \mathrm{~g}$ of sample was dispersed in $25 \mathrm{ml}$ of distilled water and homogenized for $1 \mathrm{~min}$ (separated 500 $\mu \mathrm{l}$ of dispersion was mixed with $6 \mathrm{M} \mathrm{HCl} 9.5 \mathrm{ml}$ and allow to stand overnight; $\left.\mathrm{L}_{\max }\right)$. The left dispersion was adjusted $\mathrm{pH}$ to 2.0 with $6 \mathrm{M} \mathrm{HCl}$ and mixed with pepsin $(2.86 \% \mathrm{w} / \mathrm{w}$ of substrate). The mixture was incubated and well-shaken at $37{ }^{\circ} \mathrm{C}$ for $1 \mathrm{hr}$. Then, the left mixture was adjusted to $\mathrm{pH} 5.3$ with $5 \mathrm{M} \mathrm{NaHCO}_{3}$ and then adjusted to $\mathrm{pH} 7.5$ with $5 \mathrm{M} \mathrm{NaOH}$ (separated $2 \mathrm{ml}$ of mixture $=\mathrm{L}_{1}$, stomach). The left mixture was mixed with pancreatin $(4.00 \% \mathrm{w} / \mathrm{w}$ of substrate) then incubated and well-shaken at $37{ }^{\circ} \mathrm{C}$ for $1 \mathrm{hr}$. and stopped the reaction by heated up to $95{ }^{\circ} \mathrm{C}$ for $1 \mathrm{~min}$ and cooled down at room temperature (separated 2 $\mathrm{ml}$ of mixture $=\mathrm{L}_{2}$, Small intestine). All mixtures $\left(\mathrm{L}_{1}, \mathrm{~L}_{2}\right.$ and $\left.\mathrm{L}_{\max }\right)$ were centrifuged at speed $3500 \mathrm{rpm}$ for $10 \mathrm{~min}$. The $1 \mathrm{ml}$ of supernatants were diluted and adjusted to $10 \mathrm{ml}$ with phosphate buffer $\mathrm{pH}$ 8.0. The $125 \mu \mathrm{l}$ of solutions were mixed with phosphate buffer $\mathrm{pH} 8.2$ and $0.01 \%$ TNBS $1 \mathrm{ml}$ before incubate at 50 ${ }^{\circ} \mathrm{C}$ for $30 \mathrm{~min}$ then add $2 \mathrm{ml}$ of $\mathrm{Na}_{2} \mathrm{SO}_{3}$ and allowed to stand for $15 \mathrm{~min}$ Absorbance was measured at $420 \mathrm{~nm}$ in a spectrophotometer using the buffer as blank. The in vitro protein digestibility values were calculated as percentage of digested protein at stomach $\left(\mathrm{L}_{1}\right)$ and small intestine $\left(\mathrm{L}_{2}\right)$ to total protein in snacks $\left(\mathrm{L}_{\max }\right)$. 


\section{Total phenolic content (TPC)}

Total phenolic content was determined by the Folin-Ciocalteau method described by Jiapong et al. (2011) with some modification. $5 \mathrm{~g}$ of sample (grounded) was extracted in $50 \mathrm{ml}$ of $80 \%$ methanol $(1: 10)$ covered by aluminium foil and incubate on shaker speed $150 \mathrm{rpm}$ at room temperature for $2 \mathrm{hr}$. before filtered through filter paper no.4. The sample extract $0.3 \mathrm{ml}$ was mixed with $10 \%$ FolinCiocalteu solution (in distilled water). The reaction was carried out at $25^{\circ} \mathrm{C}$ for 10 min in the dark chamber. Then $1.25 \mathrm{ml}$ of $7.5 \%$ sodium carbonate was added and the mixture was incubated again at $25^{\circ} \mathrm{C}$ for $30 \mathrm{~min}$ in the dark chamber. The absorbance of mixture was measured at wavelength $750 \mathrm{~nm}$ using a UV-visible spectrophotometer. Gallic acid $(0.0240 \mathrm{~g}$ in $25 \mathrm{ml}$ distilled water) was used to prepare a standard curve and the TPC was expressed as $\mu \mathrm{g}$ of gallic acid equivalent per $\mathrm{g}$ of dry weight snack $(\mu \mathrm{g} \mathrm{GAE} / \mathrm{g})$.

\section{Trolox equivalent antioxidant capacity (TEAC)}

The trolox equivalent antioxidant capacity was performed using 1,1-diphenyl-2picrylhydrazyl (DPPH) free-radical scavenging assay described by Sutharut $\&$ Sudarat (2012) with some modifications. The DPPH solution (3.9 mg in $100 \mathrm{ml}$ methanol) was prepared and keep in the glass bottle covered by aluminium foil to avoid the light. $1 \mathrm{~g}$ of sample (grounded) was extracted in $10 \mathrm{ml}$ of $80 \%$ methanol (1:10) and incubated on shaker speed $150 \mathrm{rpm}$ at room temperature for $2 \mathrm{hr}$. before filtered through filter paper no.4. The $1 \mathrm{ml}$ of each different concentration of trolox solution $(2.5,5.0,7.5,10.0,12.5$ and $15.0 \mathrm{ppm})$ or methanol or sample extract was mixed with $2 \mathrm{ml}$ of DPPH solution then allow to stand for $30 \mathrm{~min}$ in the dark chamber before absorbance was measured at $515 \mathrm{~nm}$ by using a UV-visible spectrophotometer and using methanol as blank. The inhibition percentage was calculated using Eq. 4. Then the inhibition percentage was plotted against the concentration of the trolox solution to obtain a trend line and equation to convert the DPPH absorbance of the extract solution to the TEAC in $\mu \mathrm{mol}$ of trolox equivalent per $\mathrm{g}$ of dry weight snack $(\mu \mathrm{mol} \mathrm{TE} / \mathrm{g})$.

\%Inhibition $=$ (absorbance of DPPH - absorbance of DPPH with tolox)/absorbance of DPPH (Eq.4)

\section{Experimental design and data analysis}

A completely Randomized Design (CRD) was used to investigate the dependent variables in this experimental. The significant differences for the different treatment combinations were calculated by using analysis of variance (ANOVA), based on Duncan's test at significant level 0.5.

\section{RESULTS AND DISCUSSION}

\section{Physical characteristic}

Figure 1 demonstrates the appearance of direct expanded Sacha inchi snacks prepared at different ratio of Sacha inchi seed meal and rice flour. There were not obviously different in appearance of snack products containing 20 to $40 \%$ Sacha inchi seed meal, whilot meal showed lower expansion with denser texture. All color data are expressed as $\mathrm{L}^{*}, \mathrm{a}^{*}$, and $\mathrm{b}^{*}$ values corresponding to lightness, redness, and yellowness, respectively (Table 3 ). In general, when the amount of Sacha inchi seed mea increased, the yellowness and the redness of snacks tend to be increased (ranged from 2.33-3.82 and 16.65-20.90, respectively). This is maybe due to the Millard reaction and the destruction of heat-sensitive pigments (Norfezah et al., 2011) and the color in extruded products is also influenced by temperature, moisture, raw material composition, residence time, pressure, shear force and screw speed (Baraiya et al., 2016). The texture analysis show that the energy to break of snacks was significantly increased when the levels of Sacha inchi seed meal and ranged from $56.76-100.03 \mathrm{kgf} \cdot \mathrm{mm}$. This is possibly due to the protein content of the snacks increased. The energy to break is a measure of the mean force that is required to break down a piece of snack and is similar to the sensory parameter of hardness. Ramos-Ramos et al. (2019) noted that the hardness of maize flour snack decreased as the percentage of fish increased. The expansion ratios of snacks ranged from 1.29 to 1.98 and were significantly decreased when the levels of Sacha inchi seed meals were increased, while the density values (ranged from $0.24-0.47 \mathrm{~g} / \mathrm{cm} 3$ ) were increased. Generally, expansion characteristics of extruded snacks have an important role in the acceptability of the final product (İbanoğlu et al., 2006) and increasing of protein and fiber contents will decrease expansion ratio and led to increasing density and hardness because of the strengthening of the foam structure of snacks (Devi et al., 2013). Navarro-Cotez et al. (2016) also reported that starch is responsible for expansion phenomenon of snack due to its viscoelastic properties and depends on the degree of gelatinization of starch. Therefore, when replaced the rice starch by increasing of the Sacha inchi seed meal which is high in protein content, the expansion ratio was decreased. Moreover, Gumul et al. (2014) found the negative correlation ratio between expansion and density of extrudates when the residue oat flour $(12.3 \%$ protein and $5.57 \%$ dietary fiber) were added into the extruded corn snack and a further increase in residue oat flour content resulted in a significant decrease in extrudate expansion and increase density. The decreased volume could also be the effect of partly liquefied starch ehich adheres to cellulose walls and reduces expansion, thus increasing the density of product. Liu et al. (2011) was also found that a higher fraction of moringa leaf $(27.1 \%$ protein and $19.2 \%$ dietary fiber) powder lead to reduced expansion of oat snack. Besides, Zambrano-Zaragoza et al. (2013) reported that the negative effects on the expansion ratio of extruded oat snacks were attributed to the use of nixtamalized corn pericarp $(34.8 \%$ dietary fiber). On the other hand, it was found that the snacks contain a higher level of Sacha inchi seed meal were required higher SME (Table 2) to the desired greater degree of starch gelatinization and extrudates expansion. (Raleng et al., 2016). This indicates that the level of Sacha inchi seed meal affects the physical characteristics of extruded snacks.

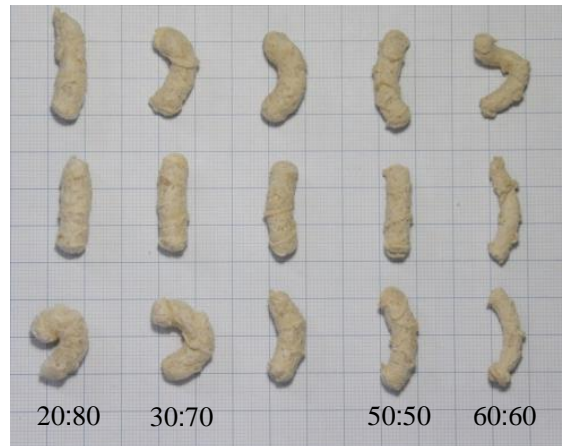

Figure 2 Appearance of direct expanded Sacha inchi snacks with different ratio of Sacha inchi seed meal and rice flour.

Table 3 Color values of direct expanded Sacha inchi snacks with different ratio of Sacha inchi seed meal and rice flour

\begin{tabular}{|c|c|c|c|c|c|c|}
\hline \multirow{2}{*}{$\begin{array}{l}\text { Sacha inchi seed meal : rice } \\
\text { flour }\end{array}$} & \multicolumn{3}{|c|}{ Color value } & \multirow{2}{*}{$\begin{array}{l}\text { Energy to break } \\
(\mathrm{kgf} \cdot \mathrm{mm})\end{array}$} & \multirow{2}{*}{ Expansion ratio } & \multirow{2}{*}{$\begin{array}{l}\text { Density } \\
\left(\mathrm{g} / \mathrm{cm}^{3}\right)\end{array}$} \\
\hline & $\mathrm{L}^{*}$ & $a^{*}$ & $\mathrm{~b}^{*}$ & & & \\
\hline $20: 80$ & $75.37 \pm 0.15^{\mathrm{a}}$ & $2.33 \pm 0.04^{d}$ & $16.65 \pm 0.06^{\mathrm{d}}$ & $58.42 \pm 11.09^{c}$ & $1.98 \pm 0.22^{\mathrm{a}}$ & $0.24 \pm 0.02^{\mathrm{c}}$ \\
\hline 30:70 & $73.61 \pm 0.50^{\mathrm{c}}$ & $2.82 \pm 0.13^{\mathrm{c}}$ & $18.93 \pm 0.37^{\mathrm{c}}$ & $59.60 \pm 7.10^{\mathrm{c}}$ & $1.91 \pm 0.12^{\mathrm{ab}}$ & $0.25 \pm 0.05^{\mathrm{c}}$ \\
\hline 40:60 & $74.64 \pm 0.14^{b}$ & $3.53 \pm 0.07^{b}$ & $19.67 \pm 0.15^{\mathrm{b}}$ & $56.76 \pm 12.96^{\mathrm{c}}$ & $1.82 \pm 0.10^{\mathrm{bc}}$ & $0.29 \pm 0.03^{\mathrm{c}}$ \\
\hline 50:50 & $73.41 \pm 0.29^{c}$ & $3.82 \pm 0.07^{\mathrm{a}}$ & $20.90 \pm 0.14^{\mathrm{a}}$ & $77.42 \pm 7.55^{\mathrm{b}}$ & $1.68 \pm 0.08^{\mathrm{c}}$ & $0.35 \pm 0.03^{b}$ \\
\hline $60: 40$ & $75.17 \pm 0.04^{\mathrm{a}}$ & $3.55 \pm 0.02^{b}$ & $20.62 \pm 0.09^{\mathrm{a}}$ & $100.03 \pm 12.99^{\mathrm{a}}$ & $1.29 \pm 0.03^{\mathrm{d}}$ & $0.47 \pm 0.07^{\mathrm{a}}$ \\
\hline
\end{tabular}

* Results are presented as mean \pm standard deviation. Mean values that contain different alphabets are significantly different at $\mathrm{p}<0.05$

\section{WAI and WSI}

The WAI measures the volume after swelling of starch on excess water and indicates the integrity of starch in aqueous dispersion (Spinello et al., 2014) and indicates the starch gelatinization index (Zambrano-Zaragoza et al., 2013). Gelatinization of starch is one of an important phenomenon in the extrusion process and is the conversion of raw starch to a cooked and digestible material by the application of water and heat (Raleng et al., 2016). The WAI depends on the availability of hydrophilic groups, which binds a molecule of water and depends on the gel-forming capacity of macromolecules (Camacho-Hernández et al. 2014). Hence, the WAI is the amount of absorbed water in the snack which usually depends on the level of starch in the extrudates (Walsh and wood, 2010). In extruded snack products, there were reported that the water-binding capacity may be affected by raw materials (particle size and moisture content) and their chemical composition including of protein, starch, and fiber content, especially the availability of hydrophilic groups of protein $(-\mathrm{OH},-\mathrm{NH} 2,-\mathrm{COOH}$, and $-\mathrm{SH})$ to extrusion process parameters (screw speed, compression ratio, and temperature) which are responsible for the chemical changes in raw material components during extrusion (Gumul et al., 2015). In this study, the WAI of direct expanded Sacha inchi snacks ranged from 5.52-6.47 (Table 4). It was found that the WAI of snacks were decreased when the levels of Sacha inchi seed meals increased, due to decreasing in normal rice starch and replaced with Sacha inchi seed meal in the products. This indicates that the WAI of snacks was significantly influenced by the level of Sacha inchi seed meal. Besides, the water plays an important role in the extrusion process as a plasticizer, gelatinization aid, and blowing agent and drives the expansion of the cell (Liu et al., 2011), 
resulting in significantly decreasing of the expansion ratios of the direct expanded Sacha inchi snacks when the levels of Sacha inchi seed meals were increased (Table 3). The WSI is used in the extrusion process as an indicator of degradation of molecular components such as starch, fiber and protein (NavarroCortez et al., 2016) and it mainly measures the amount of soluble polysaccharide released from starch after extrusion (Gat and Ananthanarayan, 2015). In this study, the WSI of direct expanded Sacha inchi snacks ranged from 6.23-7.36 and the snack contains $40 \%$ of Sacha inchi seed meal showed highest WSI. However, there are no statistical differences among the WSI of direct expanded Sacha inchi snacks at a different level of Sacha inchi seed meal from 20 to $60 \%$.

Table 4 WAI and WSI of direct expanded Sacha inchi snacks with different ratio of Sacha inchi seed meal : rice flour

\begin{tabular}{lll}
\hline $\begin{array}{l}\text { Sacha inchi seed meal : } \\
\text { rice flour }\end{array}$ & WAI & WSI \\
\hline $\mathbf{2 0 : 8 0}$ & $6.47 \pm 0.21^{\mathrm{a}}$ & $6.23 \pm 0.59^{\mathrm{a}}$ \\
$\mathbf{3 0 : 7 0}$ & $6.35 \pm 0.19^{\mathrm{a}}$ & $6.35 \pm 1.79^{\mathrm{a}}$ \\
$\mathbf{4 0 : 6 0}$ & $5.94 \pm 0.02^{\mathrm{b}}$ & $7.36 \pm 1.41^{\mathrm{a}}$ \\
$\mathbf{5 0 : 5 0}$ & $5.63 \pm 0.19^{\mathrm{c}}$ & $5.49 \pm 0.55^{\mathrm{a}}$ \\
$\mathbf{6 0 : 4 0}$ & $5.52 \pm 0.05^{\mathrm{c}}$ & $6.83 \pm 0.53^{\mathrm{a}}$ \\
\hline
\end{tabular}

*Results are presented as mean \pm standard deviation. Mean values that contain

different alphabets are significantly different at $\mathrm{p}<0.05$.

\section{Sensory evaluation}

All snack formulations (Table 1) were evaluated by the consumer judges. Product acceptant (Hedonic scaling test) is shown in table 5. In general, All snack formulations were accepted by consumers with hedonic scale means above 5 (Neither like nor dislike). The evaluation scores of snack made with $40 \%$ Sacha inchi seed meal were highest (between $7=$ like moderately to $8=$ like very much) on the hedonic scale followed by the snack made with $50 \%$ Sacha inchi seed meal with no significant difference $(\mathrm{p}<0.05)$. However, it was observed that the production of the snack made with $50 \%$ Sacha inchi seed meal by extrusion was more difficult to operate than that of snack made with $40 \%$ Sacha inchi seed meal. Moreover, it was found that the SME tend to increase when the Sacha inchi seed meal percentage increases. Overall evaluation, the snack product fortified with Sacha inchi seed meal was best at $40 \%$.

Table 5 Sensory evaluation scores of direct expanded Sacha inchi snacks with different ratio of Sacha inchi seed meal : rice flour

\begin{tabular}{lllll}
\hline Sacha inchi seed meal : rice flour & Appearance & Flavor & Texture & Overall acceptability \\
\hline $\mathbf{2 0 : 8 0}$ & $6.60 \pm 1.05^{\mathrm{b}}$ & $5.80 \pm 0.86^{\mathrm{d}}$ & $5.64 \pm 1.19^{\mathrm{b}}$ & $5.38 \pm 0.75^{\mathrm{c}}$ \\
$\mathbf{3 0 : 7 0}$ & $6.58 \pm 1.33^{\mathrm{b}}$ & $6.22 \pm 1.27^{\mathrm{cd}}$ & $5.88 \pm 1.59^{\mathrm{b}}$ & $5.84 \pm 1.39^{\mathrm{b}}$ \\
$\mathbf{4 0 : 6 0}$ & $7.62 \pm 1.14^{\mathrm{a}}$ & $7.18 \pm 0.94^{\mathrm{a}}$ & $7.04 \pm 0.95^{\mathrm{a}}$ & $7.04 \pm 1.38^{\mathrm{a}}$ \\
$\mathbf{5 0 : 5 0}$ & $7.00 \pm 0.88^{\mathrm{ab}}$ & $6.72 \pm 1.43^{\mathrm{ab}}$ & $6.88 \pm 1.35^{\mathrm{a}}$ & $7.24 \pm 0.92^{\mathrm{a}}$ \\
$\mathbf{6 0 : 4 0}$ & $6.78 \pm 1.02^{\mathrm{b}}$ & $6.60 \pm 1.39^{\mathrm{bc}}$ & $6.92 \pm 1.48^{\mathrm{a}}$ & $6.98 \pm 1.12^{\mathrm{a}}$ \\
\hline Results are presented as mean \pm standard deviation. Mean values that contain different alphabets are significantly different at $\mathrm{p}<0.05$.
\end{tabular}

Chemical composition, in vitro digestibility and antioxidant properties of direct expanded Sacha inchi snacks

The snack formulation containing $40 \%$ Sacha inchi seed meal was selected as the optimal product and analyzed for its proximate composition, in vitro digestibility and antioxidant properties and the results were shown in table 6 . The protein content of the product was $24.94 \pm 0.07 \%$, which higher than that of other snacks made with maize flour and atlantic mackerel (7.35-20.67\%) (Ramos-Ramos et al., 2019), moringa leaf and oat flour (8.25-13.66\%) (Liu et al., 2011), residual oat flour and cornmeal (7.71-8.98\%) (Gumul et al., 2015), defatted soy flour and corn grit-broken rice blends (4.93-12.12\%) (Boonyasirikul and Charunuch, 2000), pumpin and corn grit $(0.29-4.09 \%)$ (Norfezah et al., 2011), shrimp powder and rice-wheat-corn flour blends (12.69-18.74\%) Baraiya et al. (2016), fish meal and corn grits (6.82-11.85\%) (Goes et al., 2015), fish powder, corn grits and rice grits (8.9-12.0\%) (Kuna et al., 2013), horse gram flour and rice flour (6.63-11.56\%) (Gat \& Ananthanarayan, 2015), and modified sweet potato flour and mung bean flour (12.38-13.96\%) (Sunyoto et al., 2019). The percentage of fiber, fat, ash, moisture, and carbohydrate were $1.79 \pm 0.16 \%, \%$, $3.42 \pm 0.02 \%, \quad 5.61 \pm 0.14 \%$, and $62.27 \pm 0.11 \%$, respectively. The protein digestibility (in vitro) of snack was digested $12.36 \%$ in the stomach, $28.75 \%$ in the small intestine and $41.11 \%$ total protein digestibility which was lower than that of the total protein digestibility of 2 commercial snacks (70.05 and $72.21 \%)$ and low fat snack made with pinto bean and textured soybean at ratio $1: 1$ (59.11\%) reported by López-Martínez et al. (2019). The low digestibility of protein is due to the presence of anti-nutritional compounds such as tannin and maybe some other factors such as seed structure, cell wall components of the seed and the reaction of protein with non-protein components present in the seed during processing that possibility affect the digestibility of protein (Patil et al., 2016). Also, the $11 \mathrm{~S}$ globulins present in the Sacha inchi seed protein were resistant to gastric and duodenal digestion (Quinteros et al., 2016). The TPC was $205.46 \pm 11.66 \mu \mathrm{g} \mathrm{GAE} / \mathrm{g}$ dry weight snack and the TEAC was $135.40 \pm 1.10 \mu \mathrm{mol}$ $\mathrm{TE} / \mathrm{g}$ dry weight snack. These amounts were higher than that of rice flour extrudate snack reported by Gat and Ananthanarayan. (2015) which were 170 $\mu \mathrm{g} \mathrm{GAE} / \mathrm{g}$ and $3.34 \mu \mathrm{mol} \mathrm{TE} / \mathrm{g}$ snack, respectively. Besides, after replaced rice flour with horse gram flour for $30 \%$, the TPC and TEAC of snacks were increased to the range of 870-1110 $\mu \mathrm{g} \mathrm{GAE} / \mathrm{g}$ and 21.90-31.46 $\mu \mathrm{mol} \mathrm{TE} / \mathrm{g}$ rice flour extrudate snack, respectively. Thus, this result indicates that the fortified cereal-based extrudate snack with Sacha inchi seed meal can improve the antioxidant properties of the product.
Table 6 Chemical composition, in vitro digestibility and antioxidant properties of direct expanded Sacha inchi snacks

\section{Parameter}

Chemical composition

Protein (\%)

Total dietary fiber $(\%)$

$24.94 \pm 0.07$

$1.79 \pm 0.16$

Fat (\%)

Ash (\%)

$2.09 \pm 0.00$

Moisture (\%)

$3.42 \pm 0.02$

Carbohydrate (\%)

$5.61 \pm 0.14$

$62.27 \pm 0.11$

In vitro digestibility

Stomach (\%)

$12.36 \pm 0.53$

Small intestine $(\%)$

$12.36 \pm 0.53$
$28.75 \pm 0.59$

Total digestibility $(\%)$

$41.11 \pm 0.56$

Antioxidant properties

Total phenolic content ( $\boldsymbol{\mu g}$ GAE/g dry weight snack) $\quad 205.46 \pm 11.66$

TEAC ( $\mu \mathrm{mol} \mathrm{TE} / \mathrm{g}$ dry weight snack) $135.40 \pm 1.10$

*Results are presented as mean \pm standard deviation.

\section{CONCLUSION}

The level of Sacha inchi seed meal in formulations significantly affected the physical properties (color, texture, density, expansion ratio and WAI) of the direct expanded snacks. The snack fortified with $40 \%$ Sacha inchi seed meal was the most acceptable product based on the overall characteristics. The product contained higher protein $(24.94 \pm 0.07 \%)$ with lower fat content $(2.09 \pm 0.00 \%)$ and antioxidants $(205.46 \pm 11.66 \mu \mathrm{g} \mathrm{GAE} / \mathrm{g}$ and $135.40 \pm 1.10 \mu \mathrm{mol} \mathrm{TE} / \mathrm{g}$ snack) that is much healthier than several commercially available snack products $(170 \mu \mathrm{g}$ GAE/g and $3.34 \mu \mathrm{mol}$ TE/g snack). Thus, the RTE Sacha inchi snacks could be a promising protein source for the healthy food market.

Acknowledgments: This project funded by the Thailand research fund (TRF), in the research and researcher for industries (RRI) program under Grant No. PHD58I0025 and Thai C.M.S. Standard Industrial Co. Ltd. (Thailand).

\section{REFERENCES}

Adler-Nissen, J. (1979). Determination of The Degree of Hydrolysis of Food Protein Hydrolysates by Trinitrobenzenesulfonic Acid. Journal of Agricultural and Food Chemistry, 27(6), 1256 to 1262. https://doi.org/10.1021/jf60226a042 AOAC.(1990) Washington DC, USA:Association of Official Analytical Chemists. Official methods of analysis (15th ed.).

Baraiya, K. G., Zofair, S.M., Mulye, V. B., Patel, M. R., \& Gohel, J.K. (2016) Utilization of Shrimp Powder ( Solenocera crassicornis) to Develop Extruded Snack Product. Ecology, Environment and Conversvation, 22(n.d.), S25-S32.

Benjakul, S., and Morrisey M. T. (1997). Protein Hydrolysates from Pacific Whiting Solid Wastes. Journal of Agricultural and Food Chemistry, 45(9), 3423 to 3430 . https://doi.org/10.1021/jf970294g 
Boonyasirikool, P., and Charunuch, C. (2000). Development of Nutritious Soy Fortified Snack by Extrusion Cooking. Kasetsart Journal. 34(n.d.), 355-365.

Camacho-Hernández, I. L., Zazueta-Morales, J. J., Gallegos-Infante, J. A. Aguilar-Palazuelos, E., Rocha-Guzmán, N. E., Navarro-Cortez, R. O., JacoboValenzuela, N., \& Gómez-Aldapa, C. A. (2014). Effect of Extrusion Condition on Physiochemical Characteristics and Anthocyanin Content of Blue Corn ThirdGeneration Snack. CyTA - Journal of Food, 12(4), 320-330. https://doi.org/10.1080/19476337.2013.861517

Devi, N. L., Shobha, S., Tang, X., Shaur, S. A., Dogan, H, \& Alavi, S. (2013) Development of Protein-Rich Sorghum-Based Expanded Snacks Using Extrusion Technology. International Journal of Food Properties, 16(2), 263276. https://doi.org/10.1080/10942912.2011.551865

Garrett, D.A., Failla, M.L., and Sarama R. J. (1999). Development of an In Vitro Digestion Method to Assess Carotenoid Bioavailability from Meals. Journal of Agricultural and Food Chemistry, 47(10), 4301-4309. https://doi.org/10.1021/jf9903298

Gat, Y., \& Ananthanarayan, L. (2015). Physicochemical, Phytochemical and Nutritional Impact of fortified cereal-based extrude snacks. Nutrafoods, 14(3), 141-149. https://doi.org/10.1007/s13749-015-0036-7

Goes, E. S. R., Souza, M. L. R., Campelo, D. A. V., Yoshida, G. M., Xavier, T. O., Moura, L. B., \& Monteiro, A. R. G. (2015). Extruded Snacks with the Addition of Different Fish Meals. Food Science and Technology, 35(4), 683-689. https://doi.org/10.1590/1678-457x.6818

Gropper, M., Moraru, C. I., \& Kokini, J. L. ( 2002). Effect of Specific Mechanical Energy on Properties of Extruded Protein-Starch Mixtures. Cereal Chemistry, 79(3), 429-433. https://doi.org/10.1094/cchem.2002.79.3.429

Gumul, D., Ziobro, R., Gambuś, H, \& Nowotna, A. (2014). Usability of Residual Oat Flour in the Manufacture of Extruded Corn Snacks. CyTA - Journal of Food, 13(3), 353-360. https://doi.org/10.1080/19476337.2014.984336

Hamaker, B. R., Valles, C., Gilman, R., Hardmeier, R. M., Clark, D., Garcia, H. H., \& Lescano, M.. (1992). Amino Acid and Fatty Acid Profile of the Inca Peanut (Plukenetia volubilis). Cereal Chem, 69(4), 461-463.

Hanssen H., Schmitz-Hübsch M. (2011). Sacha Inchi (Plukenetia volubilis L.) Nut Oil and Its Therapeutic and Nutritional Uses. Nuts and Seeds in Health and Disease Prevention. San Diego: Academic Press. 991-994. https://doi.org/10.1016/b978-0-12-375688-6.10117-3

İbanoğlu, S., Ainsworth, P., Özer, E. A., \& Plunkett, A. (2006). Physical and Sensory Evaluation of a Nutritionally Balanced Gluten-Free Extruded Snack. Journal of Food Engineering, 75(4), 469472. https://doi.org/10.1016/i.jfoodeng.2005.04.060

Jiapong, S., Singanusong, R., \& Jiamyangyuen, S. (2011). Effect of Germination on Antioxidative Property of Pigmented and Non-Pigmented rice. Thai Journal of Agricultural Science, 44(5), 277-282.

Kuna, A., Devi, N. L., \& Kalpana, K. (2013). Utilization of Fish Powder in Ready-to-Eat Extruded Snacks. Fishery Technology, 50(3), 245-250.

Lim, J. (2011). Hedonic Scaling: A Review of Methods and Theory. Food Quality and Preference, 22, 733-747. https://doi.org/10.1016/j.foodqual.2011.05.008

Liu, S., Alavi, S., \& Abughoush, M. (2011). Extruded Moringa Leaf-Oat Flour Snacks: Physical, Nutritional, and Sensory Properties. International Journal of Food Properties, 14(4), 854-869. https://doi.org/10.1080/10942910903456358 López-Martínez, A., Azuara-Pugliese, V., Sánchez-Macias, A., Sosa-Mendoza, G., Dibildox-Alvarado, E., \& Grajales-Lagunes, A. (2019). Hogh Protein and Low-Fat Chips (Snack) Made Out of A Legume Mixture. CyTA - Journal of Food, 17(1), 661-668. https://doi.org/10.1080/19476337.2019.1617353

Navarro-Cortez, R. O., Hernández-Santos, B., Gómez-Aldapa, C. A., CastroRosas, J., Herman-Lara, E., Martínez-Sánchez, C. E., \& Rodríguez-Miranda, J. (2016). Development of Extruded Ready-to-eat Snacks Using Pumpkin Seed (Cucurbita pepo) and Nixtanalized Maize (Zea mays) Flour Blends. Reviata Mexicana de Ingeniería química, 15(2), 409-422.

Norfezah, M. N., Hardacre, A., \& Brennan, C. S. (2011). Comparison of Waste Pumpkin Material and Its Potential Use in Extruded Snack Foods. Food Science and Texhnology International, 17(4), 367-373. https://doi.org/10.1177/1082013210382484

Patil, S. S., Brennan, M. A., Mason, S. L., \& Brennan, C. S. (2016) The Effects of Fortification of Legumes and Extrusion on the Protein Digestibility of Wheat Based Snack. Foods, 5(26), 1-8. https://doi.org/10.3390/foods5020026

Quinteros, M. F., Vilcacundo, R., Carpio, C., \& Carrillo, W. (2016). Digestibility and Anti-inflammatory Activity in Vitro of Sacha Inchi (Plukenetia volubilis L.) Proteins. Asian Journal of Pharmaceutical and Clinical Research, 9(3), 303-306. Raleng, A., Singh, A., \&Attkan, A. K. (2016). Response Surface Methodology for Development and Characterization of Extruded Snack Development from Food-by-products. International Journal of Bio-resource and Stress Management, 7(6), 1321-1329. https://doi.org/10.23910/ijbsm/2016.7.6.1691a

Ramos-Ramos, M., Rodríguez-Castillejos, G., Santiago-Adame, R., AlemánCastillo, S.E., Castillo-Ruiz, O., \& Perales-Torres, A.L. (2019). Production and Characterization of a Snack Based on Maize Flour and Atlantic Mackerel (Scomber Scombrus). CyTA - Journal of Food, 17(1), 1006-1013. https://doi.org/10.1080/19476337.2019.1690584
Spinello, A. M., Leonel, M., Mischan, M. M., \& Carmo, E. L. (2014). Cassava and Tumeric Flour Blends as New Raw Materials to Extruded Snacks. Ciência e Agrotecnologia, $38(1), \quad 68-75 . \quad$ https://doi.org/10.1590/s141370542014000100008

Sutharut, J., \& Sudarat, J. (2012). Total Anthocyanin Content and Antioxidant Activity of Germinated Colored Rice. International Food Research Journal, 19(1), 215-221.

Sunyoto, M., Andoyo, R., and Masitoh, E. (2019). Characteristics of High Protein Snack Bar Made of Modified Sweet Potato Flour. 6th International Conference on Sustainable Agriculture, Food and Energy IOP Conf. Series: Earth and Environmental Science 347, IOP Publishing. https://doi.org/10.1088/1755$1315 / 347 / 1 / 012064$

Walsh, M. K., \& Wood, A. M. (2010). Properties of Extrusion-Expanded Whey Protein Products Containing Fiber. International Journal of Food Properties, 13(4), 702-712. https://doi.org/10.1080/10942910902800515

Zambrano-Zaragoza, M. L., Gutiérrez-Cortez, E., Jiméenez-Vieyra, M. E., Gallardo-Navarro, T. T., Cornejo-Villegas, M. A., \& Quintanar-Guerrero, D. (2013). Effects of Extrusion Process in Snacks of Oats-Nixtamalized Corn Pericarp Mixtures on Dietary Fiber Content and Functional Properties. CyTA Journal of Food, 11(1), 38-45. https://doi.org/10.1080/19476337.2012.763046 